difficult, since it did not obviate the need for laparotomy. Of the 12 patients with jaundice on whom the test was carried out five had stones in the common bile duct, two had carcinoma of the hepatic duct, and five had carcinoma of the head of the pancreas. Cytological examination predicted the presence or absence of carcinoma with considerable accuracy.

The triple test of Youngs et al. (1973) failed to diagnose carcinoma in one-third of the patients by the two intubation tests, and the abnormal pancreatic scans were not in themselves diagnostic of carcinoma. In the present study the additional information obtained from duodenography and cytology resulted in a correct diagnosis of carcinoma in all but one patient. A preoperative diagnosis of carcinoma of the pancreas allows suitable adjustment of preoperative preparation and also obviates the need for biopsy of a pancreatic mass, which may be misleading and dangerous. With increasing experience we hope that the accuracy of preoperative diagnosis will be improved further.

We wish to thank the technical and nursing staff for their help with the tests.

Requests for reprints should be addressed to: Dr. J. H. Baron, Department of Surgery, Royal Postgraduate Medical School, Hammersmith Hospital, London W12 0HS.

\section{References}

Agnew, J. E., Youngs, G. R., and Bouchier, I. A. D. (1973). British fournal of Radiology, 46, 83.

Asnaes, S., and Johansen, A. (1970). Acta Pathologica et Microbiologica Scandinavica, Suppl. No. 212, p. 11 .

Bank, S., Marks, I. N., Moshal, G. F., Efron, G., and Silber, R. (1963). South African Medical fournal, 37, 1061.

Bourke, J. B., Swann, J. C., Brown, C. L., and Ritchie, H. D. (1972). Lancet, 1, 605 .

Braganza, J., Critchley, M., Howat, H. T., Testa, H. J., and Torrance, H. B. (1973). Gut, 14, 383.

Dreiling, D. A. (1971). In The Exocrine Pancreas. ed. I. T. Beck and D. G. Sinclair, Chap. 12, p. 154. London, Churchill.

Elias, E., et al. (1972). Lancet, 2, 791.

Gutierrez, L. V., and Baron, J. H. (1972). Gut, 13, 721.

McCarthy, D. M., and Brown, P. (1969). Gut, 10, 913.

McCarthy, D M., Brown, P., Melmed, R. N., Agnew, J. E., and Bouchier, I. A. D. (1972). Gut, 13, 75.

McCarthy, D. M., Kreel, L., Agnew, J. E., and Bouchier, I. A. D. (1969). Gut, 10, 665 .

McCready, V. R., and Cottrall, M. F. (1971). British fournal of Radiology, $44,870$.

Raia, S., and Kreel, L. (1966). Gut, 7, 420.

Rankin, G. V., and Brown, C. H. (1964). Cleveland Clinical Quarterly, 31, 119.

Sodee, D. B. (1964). Medical Radioisotope Scanning. 2nd Athens Symposium. Stage, P., and Banke, L. (1969). Gut, 10, 428.

Wormsley, K. G. (1968). Gastroenterology, 54, 197.

Wormsley, K. G. (1969). Scandinavian fournal of Gastroenterology, 4, 623. Wormsley, K. G. (1970). Proceedings of the Royal Society of Medicine, 63, 431. Youngs, G. R., Agnew, J. E., Levin, G. E., and Bouchier, I. A. D. (1971). British Medical fournal, 2, 252.

Youngs, G. R., Agnew, J. E., Levin, G. E., and Bouchier, I. A. D. (1973). Quarterly fournal of Medicine, 42, 597 .'

\title{
Response of Leucocyte Adenyl Cyclase to Isoprenaline and Effect of Alpha-blocking Drugs in Extrinsic Bronchial Asthma
}

\author{
W. C. ALSTON, K. R. PATEL, J. W. KERR
}

British Medical fournal, 1974, 1, 90-93

\section{Summary}

The finding by several workers that biochemical responses to catecholamines are diminished in asthmatic patients during periods of active asthma as compared to normal subjects has led to the recognition of the betaadrenergic blockade phenomenon, a common accompaniment of extrinsic bronchial asthma. Using an intact cell method to measure leucocyte adenyl cyclase activity, we have been able to show that there is a noticeably reduced responsiveness of this enzyme system (which is now identified with beta-receptor function) to isoprenaline in the leucocytes of patients suffering from acute bronchial asthma, but that asthmatic patients in remission could not be distinguished from normal persons in this respect. Evidently the defective beta-receptor function may be associated with overactivity of the alphareceptors in acute bronchial asthma, since the responsiveness to isoprenaline stimulation could be restored towards normal by concomitant treatment of the leucocytes of these patients with alpha-receptor blocking drugs such as phentolamine or thymoxamine. Ouabain, though

Department of Biochemistry, Western Infirmary, Glasgow G11 6NT W. C. ALSTON, PH.D., M.R.C.PATH., Senior Registrar K. R. PATEL, M.B., M.R.C.P., Research Fellow. J. W. KERR, M.D., F.R.C.P., Consultant Physician

somewhat less potent, also enhanced responsiveness to isoprenaline stimulation. The relation of these results to the clinical observation of adrenaline resistance in active asthma suggests that alpha-receptor blocking drugs may be of value in restoring the sensitivity of beta-receptors to sympathomimetic amines.

\section{Introduction}

Patients suffering from extrinsic bronchial asthma have a greater tolerance to adrenaline than normal persons. This resistance or "adrenaline fastness" is most pronounced in patients in. status asthmaticus. Resistance to adrenaline can be produced in laboratory animals with agents such as Bordetella pertussis vaccine, whose actions are now known to include beta-receptor blocking activity. From clinical observations and experimental investigation of these findings Szentivanyi (1968) suggested an autonomic neural imbalance with decreased beta-adrenergic responsiveness to explain the atopic state in bronchial-asthma. The association of the beta-adrenergic receptor function with adenyl cyclase activity by Robison et al. (1967) paved the way for a more fundamental investigation of the nature of the refractoriness to catecholamines in patients with bronchial asthma. The report by Scott (1970) of adenyl cyclase activity in broken cell preparations from human leucocytes prompted other investigators (Bourne and Melmon, 1971) to examine the adenyl cyclase system in intact leucocytes and its responsiveness to stimulation by adrenergic agonists and antagonists. Smith and Parker (1970) first reported that the peripheral-blood leucocytes of some asthmatic patients had a reduced adenyl cyclase responsiveness to catecholamines compared to that in normal 
subjects. Coffey et al. (1972 a, b) observed a diminished leucocyte adenyl cyclase stimulation by isoprenaline in almost all the asthmatics they studied, whereas Gillespie et al. (1973) failed to find any difference in this respect between their asthmatic patients and normal persons. We have measured the leucocyte adenyl cyclase response to isoprenaline in relation to the activity of asthma and the degree of airways obstruction, and have studied alpha-receptor function by using alpha-blocking agents together with the beta-agonist.

\section{Patients and Methods}

Fourteen outpatients, aged from 17 to 42 years, with reversible airways obstruction due to extrinsic bronchial asthma were studied. Their skin tests showed a positive response to inhalant allergens, a blood eosinophil count of over $500 \mathrm{cells} / \mathrm{mm}^{3}$, and 10 of the patients had associated atopic diseases such as eczema, allergic rhinitis, or hay fever. Some patients were on daily maintenance therapy with bronchodilators-for example, salbutamol aerosol-five were on disodium cromoglycate, three on beclomethasone dipropionate by inhalation, and one was on 20 units of corticotrophin gelatin by injection once weekly. All therapy was discontinued for at least 24 hours before the experiments, and the ACTH was stopped for one week beforehand.

The patients were divided into two groups. The first consisted of seven patients with active asthma as assessed by a history of daily wheezing, breathlessness on moderate exercise, clinical and spirometric evidence of airways obstruction, and the amount of bronchodilator and steroid therapy required for the relief of symptoms. The second group consisted of seven asthmatic patients in remission. Ten healthy adults aged from 19 to 45 years without respiratory or atopic disease were studied as a control group. Samples of venous blood were collected between 9 and 10 a.m. to avoid circadian variations. Blood films from each patient and also from a few controls were made for differential leucocyte count. The forced expiratory volume in one second $\left(\mathrm{FEV}_{1}\right)$ was measured with a Garthur Vitalograph spirometer.

\section{REAGENTS}

The reagents used were as follows: adenosine triphosphate (ATP), adenosine diphosphate (ADP), 5'-adenosine monophosphate (5'-AMP), and 3'-5' cyclic adenosine monophosphate (cyclic AMP), adenosine, adenine, human serum albumin, theophylline, ouabain octahydrate, DL isoprenaline hydrochloride (all from the Sigma Chemical Co.), phentolamine mesylate (Ciba Laboratories Ltd.), thymoxamine hydrochloride (William R. Warner \& $\mathrm{Co}$.), and ${ }^{3} \mathrm{H}$-adenine $(15 \mathrm{Ci} /$ mmol) (Radio Chemical Centre, Amersham). The scintillation grade chemicals naphthalene, 2, 5-diphenyloxazole (PPO), toluene, 1, 4-dioxan, and 2-ethoxyethanol and also the Whatman $3 M M$ chromatography paper were purchased from BDH Chemicals Ltd.

\section{PREPARATION OF LEUCOCYTES}

Leucocytes were prepared from about $40 \mathrm{ml}$ of whole blood according to the dextran sedimentation technique described by Logsdon et al. (1972 b), and the cells were resuspended in a buffered solution containing $0 \cdot 12 \mathrm{mmol} \mathrm{Na} \mathrm{Cl} / 1$., $5 \mathrm{mmol} \mathrm{KCl} / 1$., $0.6 \mathrm{mmol} \mathrm{Ca} \mathrm{Cl} / 1 ., 1 \mathrm{mmol} \mathrm{Mg} \mathrm{Cl}_{2} / 1 ., 10 \mathrm{mmol}$ glucose/l., $0.3 \mathrm{~g} / \mathrm{l}$. human albumin, $25 \mathrm{mM}$ TRIS $\mathrm{HCl}$, and $20 \%(\mathrm{v} / \mathrm{v})$ human $\mathrm{AB}$ rhesus-positive serum adjusted to $\mathrm{pH} 7 \cdot 40$.

\section{ADENYL CYCLASE ASSAY}

Leucocyte adenyl cyclase assay was performed by the following modification of the intact cell method described by Humes et al.
(1969): $2 \mathrm{ml}$ of a suspension of the leucocytes in the buffered culture medium described, containing between 150 and $200 \times 10^{\circ}$ cells, were incubated with shaking at $37^{\circ} \mathrm{C}$ for two hours with ${ }^{3} \mathrm{H}$-adenine $\left(1 \mu \mathrm{Ci} / 5 \times 10^{6}\right.$ cells $)$ in a siliconized conical centrifuge tube. After incubation the cells were centrifuged at $150 \mathrm{~g}$ for five minutes and the supernatant fluid removed. The cells were then washed three times with fresh culture medium to remove as completely as possible the extracellular labelled adenine, and were resuspended in fresh medium to give a concentration of about $10 \times 10^{8}$ cells $/ \mathrm{ml}, 0.5 \mathrm{ml}$ quantities of which were then added to siliconized tubes and once again incubated in a shaking metabolic water bath at $37^{\circ} \mathrm{C}$ for 15 minutes to allow temperature equilibration to occur. Then $0.5 \mathrm{ml}$ of a solution of $20 \mathrm{mmol}$ theophylline/1. dissolved in buffered culture medium was added to the cell suspension. The beta-adrenergic agonist or alphablocking agent was added at the same time as theophylline. The cells were incubated for a further five minutes and the reaction was terminated by boiling the reaction tubes for three minutes. A non-radioactive carrier solution, $0.1 \mathrm{ml}$ containing $5 \mathrm{mmol} / 1$. each of $3^{\prime}-5^{\prime}$ cyclic AMP, ATP, ADP, 5'-AMP adenosine, and adenine, was then added and after thorough mixing the tubes were centrifuged. All incubations were performed in duplicate and the use of the $A B$ rhesus-positive serum helped to prevent aggregation of the cells. Aliquots of $40 \mu \mathrm{l}$ of the protein-free supernatant solution spotted on Whatman $3 \mathrm{MM}$ paper were subjected to chromatography for 14 hours in a solvent system consisting of $1 \mathrm{M}$ ammonium acetate $(\mathrm{pH} \mathrm{7.5)}$ and ethanol (30:75) (Humes et al., 1969) which effectively separates 3'-5' cyclic AMP $\left(R_{f} 0.40\right)$ from ATP, ADP, 5'-AMP ( $R_{f}$ Oto 0.13), adenosine $\left(R_{f} 0.61\right)$, and adenine $\left(R_{f} 0.69\right)$. After drying the chromatogram the positions of the spots were located under ultraviolet light and identified by means of markers in addition to mobilities. The areas corresponding to $3^{\prime}-5^{\prime}$ cyclic AMP, adenine plus adenosine, and ATP plus ADP plus 5 -AMP were cut out with scissors and placed in separate vials. The nucleotides and purine bases were eluted from the paper with $1 \mathrm{ml}$ of $10 \mathrm{mM}$ TRIS $\mathrm{HCl}(\mathrm{pH} \mathrm{7.4})$ and $15 \mathrm{ml}$ of a scintillation fluid, consisting of a mixture of $4 \mathrm{~g} \mathrm{PPO}$,

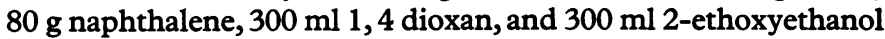
made up to 1 litre with toluene was added. The vials were then counted in a Beckman scintillation counter with a counting efficiency of $30 \%$ for ${ }^{3} \mathrm{H}$.

\section{ANALYSIS OF DATA}

Following the procedure devised by Logsdon et al. (1972 b), adenyl cyclase activity was calculated as the ratio of ${ }^{3} \mathrm{H}$-cyclic $A M P$ to the total activity found in ATP, ADP, 5'-AMP, cyclic $A M P$, adenosine, and adenine expressed as a percentage. This method avoids differences in the uptake of ${ }^{3} \mathrm{H}$-adenine by the cells in different sample tubes. The percentage of cyclic AMP formed in the control tubes containing only theophylline was taken as the control for each experiment. The percentage of cyclic AMP formed after each drug treatment was then divided by the control value for that experiment so that each treatment was expressed as a percentage of the control value, thus making possible comparisons between the various treatments in each experiment and between experiments. Results from separate experiments were pooled and group means calculated plus or minus the standard error of the mean. Student's $t$ test was used to determine the significance of drug effects.

\section{Results}

The detailed results for each group of subjects are shown in tables I, II, and III, together with the statistical evaluation. There was a significant difference in the mean percentage value of ${ }^{8} \mathrm{H}$-cyclic AMP in the control (or basal level) between the active asthmatic group $(1.48 \pm 0.21)$ and the asthmatic group in 
TABLB I-The Leucocyte Adenyl Cyclase Response to Isoprenaline and the Effect of Ouabain, Thymoxamine, and Phentolamine on this Response in Normal Subiects

\begin{tabular}{|c|c|c|c|c|c|c|c|c|c|c|c|}
\hline \multirow{2}{*}{$\begin{array}{l}\text { Case } \\
\text { No. }\end{array}$} & \multirow[b]{2}{*}{ Age } & \multirow[b]{2}{*}{ Sex } & \multirow{2}{*}{$\begin{array}{l}\text { Control } \\
\text { Value }\end{array}$} & \multicolumn{2}{|c|}{ Isoprenaline } & \multicolumn{2}{|c|}{ Ouabain $2 \times 10^{-4} \mathrm{M}$} & \multicolumn{2}{|c|}{ Thymoxamine $2 \times 10^{-4} \mathrm{M}$} & \multicolumn{2}{|c|}{ Phentolamine $2 \times 10^{-4} \mathrm{M}$} \\
\hline & & & & $10^{-6} \mathrm{M}$ & $10^{-4} \mathrm{M}$ & Alone & $+\underset{10^{-4} M}{\text { Isoprenaline }}$ & Alone & $\underset{10^{-4} M}{\text { Isoprenaline }}$ & Alone & $+\underset{10^{-4} M}{\text { Isoprenaline }}$ \\
\hline $\begin{array}{r}1 \\
2 \\
3 \\
4 \\
5 \\
6 \\
7 \\
8 \\
9 \\
10\end{array}$ & $\begin{array}{l}32 \\
28 \\
21 \\
23 \\
24 \\
19 \\
25 \\
33 \\
45 \\
25\end{array}$ & $\begin{array}{l}\text { M. } \\
\text { M. } \\
\text { F. } \\
\text { M. } \\
\text { M. } \\
\text { M. } \\
\text { M. } \\
\text { M. } \\
\text { M. }\end{array}$ & $\begin{array}{l}0.86 \\
0.57 \\
1.05 \\
3.45 \\
0.95 \\
1.23 \\
0.49 \\
1.09 \\
0.86 \\
1.03\end{array}$ & $\begin{array}{r}134.9 \\
101.8 \\
134.3 \\
132.8 \\
214.7 \\
113.8 \\
146.9 \\
96.3 \\
339.5 \\
196.1\end{array}$ & $\begin{array}{r}147.7 \\
131.6 \\
155.2 \\
159.4 \\
196.8 \\
127.6 \\
134.7 \\
91.7 \\
94.2 \\
203.9\end{array}$ & $\begin{array}{r}140.7 \\
140.4 \\
117.1 \\
37.4 \\
128.4 \\
64.2 \\
108.2 \\
60.6 \\
34.9 \\
59.2\end{array}$ & $\begin{array}{r}164.0 \\
156.1 \\
161.9 \\
113.9 \\
201.1 \\
126.0 \\
1777.6 \\
92.7 \\
120.9 \\
230.1\end{array}$ & $\begin{array}{r}109.3 \\
119.3 \\
101.0 \\
90.7 \\
150.5 \\
88.6 \\
118.4 \\
120.2 \\
74.4 \\
150.5\end{array}$ & $\begin{array}{l}160.5 \\
235.1 \\
161.0 \\
132.2 \\
273.7 \\
153.7 \\
144.9 \\
164.2 \\
134.9 \\
254.4\end{array}$ & $\begin{array}{r}130.2 \\
164.9 \\
109.5 \\
95.9 \\
160.0 \\
63.4 \\
122.4 \\
82.6 \\
81.4 \\
87.4\end{array}$ & $\begin{array}{r}327.9 \\
226.3 \\
203.8 \\
123.2 \\
307.4 \\
67.5 \\
228.6 \\
111.9 \\
191.9 \\
289.3\end{array}$ \\
\hline Mean & & & $\begin{array}{c}1 \cdot 15 \\
(0 \cdot 26)\end{array}$ & $\begin{array}{l}161 \cdot 1 \\
(23 \cdot 2)\end{array}$ & $\begin{array}{l}144 \cdot 3 \\
(11 \cdot 8)\end{array}$ & $\begin{array}{c}89 \cdot 1 \\
(13 \cdot 3)\end{array}$ & $\begin{array}{l}154 \cdot 4 \\
(13 \cdot 3)\end{array}$ & $\begin{array}{c}112 \cdot 3 \\
(7 \cdot 9)\end{array}$ & $\begin{array}{l}181 \cdot 5 \\
(16.5)\end{array}$ & $\begin{array}{l}109 \cdot 8 \\
(10 \cdot 8)\end{array}$ & $\begin{array}{l}207 \cdot 8 \\
(27 \cdot 5)\end{array}$ \\
\hline $\mathbf{P}$ & & & & 0.02 & 0.005 & $0 \cdot 25$ & 0.005 & $0 \cdot 10$ & 0.001 & 0.40 & 0.005 \\
\hline
\end{tabular}

Values in parenthesis $=1$ Standard error of mean.

The control value represents the basal level of incorporation of ${ }^{2} \mathrm{H}$-adenine into cyclic AMP and the results for the drugs are given as a percentage of the control calculated by the method described in the text.

TABLE II-The Leucocyte Adenyl Cyclase Response to Isoprenaline and the Effect of Ouabain, Thymoxamine, and Phentolamine upon this Response in Patients with Acute Asthma

\begin{tabular}{|c|c|c|c|c|c|c|c|c|c|c|c|}
\hline \multirow{2}{*}{$\begin{array}{l}\text { Case } \\
\text { No. }\end{array}$} & \multirow[b]{2}{*}{ Age } & \multirow[b]{2}{*}{ Sex } & \multirow{2}{*}{$\begin{array}{l}\text { Control } \\
\text { Value }\end{array}$} & \multicolumn{2}{|c|}{ Isoprenaline } & \multicolumn{2}{|c|}{ Ouabain $2 \times 10^{-4} \mathrm{M}$} & \multicolumn{2}{|c|}{ Thymoxamine $2 \times 10^{-4} \mathrm{M}$} & \multicolumn{2}{|c|}{ Phentolamine $2 \times 10^{-4} \mathrm{M}$} \\
\hline & & & & $10^{-6} \mathrm{M}$ & $10^{-4} M$ & Alone & $\begin{array}{c}\text { Isoprenaline } \\
10^{-4} \mathrm{M}\end{array}$ & Alone & $+\underset{10^{-4} M}{\text { Isoprenaline }}$ & Alone & $+\underset{10^{-4} M}{\text { Isoprenaline }}$ \\
\hline $\begin{array}{l}11 \\
12 \\
13 \\
14 \\
15 \\
16 \\
17\end{array}$ & $\begin{array}{l}17 \\
17 \\
30 \\
42 \\
31 \\
36 \\
19\end{array}$ & $\begin{array}{l}\text { F. } \\
\text { F. } \\
\text { F. } \\
\text { M. } \\
\text { M. } \\
\text { M. } \\
\text { M. }\end{array}$ & $\begin{array}{l}1.12 \\
1.81 \\
0.98 \\
1.20 \\
0.92 \\
2.0 \\
2.36\end{array}$ & $\begin{array}{r}110.7 \\
111.6 \\
94.9 \\
125.0 \\
150.0 \\
82.5 \\
95.3\end{array}$ & $\begin{array}{r}122.3 \\
127.6 \\
55.1 \\
130.0 \\
139.1 \\
108.5 \\
104.2\end{array}$ & $\begin{array}{r}87.5 \\
114.9 \\
77.6 \\
152.5 \\
108.7\end{array}$ & $\begin{array}{l}132.1 \\
135.4 \\
121.4 \\
210.0 \\
152.2\end{array}$ & $\begin{array}{r}122.3 \\
100.0 \\
75.5 \\
131.7 \\
87.0\end{array}$ & $\begin{array}{l}206.3 \\
168.5 \\
146.9 \\
231.7 \\
173.9\end{array}$ & $\begin{array}{r}161.6 \\
121.5 \\
69.4 \\
195.0 \\
117.4\end{array}$ & $\begin{array}{l}207 \cdot 1 \\
144 \cdot 2 \\
149 \cdot 0 \\
184 \cdot 2 \\
187 \cdot 0\end{array}$ \\
\hline Mean & & & $\begin{array}{c}1.48 \\
(0.21)\end{array}$ & $\begin{array}{r}110 \cdot 0 \\
(8 \cdot 5)\end{array}$ & $\begin{array}{l}112 \cdot 4 \\
(10 \cdot 6)\end{array}$ & $\begin{array}{l}108 \cdot 2 \\
(13 \cdot 0)\end{array}$ & $\begin{array}{l}150 \cdot 2 \\
(15 \cdot 7)\end{array}$ & $\begin{array}{l}103 \cdot 3 \\
(10 \cdot 5)\end{array}$ & $\begin{array}{l}185 \cdot 5 \\
(15 \cdot 0)\end{array}$ & $\begin{array}{l}132 \cdot 0 \\
(22 \cdot 0)\end{array}$ & $\begin{array}{l}174 \cdot 3 \\
(12 \cdot 0)\end{array}$ \\
\hline $\mathbf{P}$ & & & & $0 \cdot 30$ & $0 \cdot 20$ & 0.60 & 0.02 & $0 \cdot 80$ & 0.001 & $0 \cdot 20$ & 0.001 \\
\hline
\end{tabular}

Values in parenthesis $=1$ standard error of mean.

The control value represents the basal level of incorporation of ${ }^{2} \mathrm{H}$-adenine into cyclic AMP and the results for the drugs are given as a percentage of the control calculated by the method described in the text.

TABLE III-The Leucocyte Adenyl Cyclase Response to Isoprenaline and the Effect of Ouabain, Thymoxamine, and Phentolamine on this Response in Asthmatic Patients in Remission

\begin{tabular}{|c|c|c|c|c|c|c|c|c|c|c|c|}
\hline \multirow{2}{*}{$\begin{array}{l}\text { Case } \\
\text { No. }\end{array}$} & \multirow[b]{2}{*}{ Age } & \multirow[b]{2}{*}{ Sex } & \multirow{2}{*}{$\begin{array}{l}\text { Control } \\
\text { Value }\end{array}$} & \multicolumn{2}{|c|}{ Isoprenaline } & \multicolumn{2}{|c|}{ Ouabain $2 \times 10^{-4} \mathrm{M}$} & \multicolumn{2}{|c|}{ Thymoxamine $2 \times 10^{-4} \mathrm{M}$} & \multicolumn{2}{|c|}{ Phentolamine $2 \times 10^{-4} \mathrm{M}$} \\
\hline & & & & $10^{-6} \mathrm{M}$ & $10^{-4} \mathrm{M}$ & Alone & $+\underset{10^{-4} M}{\text { Isoppraline }}$ & Alone & $\underset{10^{-4} M}{\text { Isoprenaline }}$ & Alone & $\begin{array}{c}\text { + Isoprenaline } \\
10^{-4} \mathrm{M}\end{array}$ \\
\hline $\begin{array}{l}18 \\
19 \\
20 \\
21 \\
22 \\
23 \\
24\end{array}$ & $\begin{array}{l}18 \\
28 \\
21 \\
27 \\
23 \\
20 \\
23\end{array}$ & $\begin{array}{l}\text { M. } \\
\text { M. } \\
\text { M. } \\
\text { M. } \\
\text { F. } \\
\text { M. } \\
\text { M. }\end{array}$ & $\begin{array}{l}0.29 \\
0.81 \\
0.58 \\
0.52 \\
0.66 \\
0.65 \\
0.98\end{array}$ & $\begin{array}{r}151 \cdot 7 \\
222 \cdot 2 \\
179 \cdot 3 \\
161 \cdot 5 \\
97 \cdot 0 \\
223 \cdot 1 \\
115 \cdot 3\end{array}$ & $\begin{array}{l}189 \cdot 7 \\
218 \cdot 5 \\
165 \cdot 5 \\
211 \cdot 5 \\
183 \cdot 3 \\
230 \cdot 8 \\
149 \cdot 0\end{array}$ & $\begin{array}{r}137.9 \\
140.7 \\
132.8 \\
125.0 \\
210.6 \\
87.7\end{array}$ & $\begin{array}{l}158 \cdot 6 \\
251.9 \\
219 \cdot 0 \\
205 \cdot 8 \\
172 \cdot 7 \\
213.8\end{array}$ & $\begin{array}{r}120 \cdot 7 \\
151 \cdot 9 \\
105 \cdot 2 \\
92 \cdot 3 \\
137 \cdot 9 \\
109 \cdot 2\end{array}$ & $\begin{array}{l}269 \cdot 0 \\
318 \cdot 5 \\
210 \cdot 3 \\
225 \cdot 0 \\
263 \cdot 6 \\
292 \cdot 3\end{array}$ & $\begin{array}{l}286 \cdot 2 * \\
127 \cdot 2 \\
112 \cdot 1 \\
151 \cdot 9 \\
154 \cdot 5 \\
98.5\end{array}$ & $\begin{array}{c}1,724 \cdot 0^{*} \\
330 \cdot 9 \\
244 \cdot 8 \\
301 \cdot 9 \\
234 \cdot 8 \\
333 \cdot 8\end{array}$ \\
\hline Mean & & & $\begin{array}{c}0.64 \\
(0.08)\end{array}$ & $\begin{array}{l}164 \cdot 0 \\
(18 \cdot 3)\end{array}$ & $\begin{array}{l}192 \cdot 6 \\
(11 \cdot 1)\end{array}$ & $\begin{array}{l}139 \cdot 1 \\
(16 \cdot 3)\end{array}$ & $\begin{array}{l}203 \cdot 6 \\
(13 \cdot 7)\end{array}$ & $\begin{array}{r}119 \cdot 5 \\
(9 \cdot 0)\end{array}$ & $\begin{array}{l}263 \cdot 1 \\
(16 \cdot 5)\end{array}$ & $\begin{array}{l}128 \cdot 8 \\
(11 \cdot 0)\end{array}$ & $\begin{array}{l}289 \cdot 2 \\
(21 \cdot 0)\end{array}$ \\
\hline $\mathbf{P}$ & & & & 0.005 & 0.001 & 0.05 & 0.001 & $0 \cdot 10$ & 0.001 & $0 \cdot 20$ & 0.001 \\
\hline
\end{tabular}

Yalues in parenthesis $=1$ standard error of mean.

The control value represents the basal level of incorporation of ${ }^{3} \mathrm{H}$-adenine into Cyclic AMP and the results for the drugs are given as a percentage of the control calculated by the method described in the text.

* These values were omitted from the calculation of the group mean values to avoid undue statistical weighting of the results by the undue sensitivity of this patient to phentolamine and isoprenaline.

remission $(0.64 \pm 0.08, \mathrm{P}<0.005)$ but not between the active asthmatic group and the normal group (1.15 $\pm 0 \cdot 26)$.

The difference between the normal group and the asthmatics in remission was also not significant (paired Student's $t$ tests).

In the normal subjects isoprenaline at $10^{-6} \mathrm{~mol} / \mathrm{l}$. and also $10^{-4} \mathrm{~mol} / \mathrm{l}$. evoked significant increases in leucocyte adenyl cyclase activity, 61\% $(P<0.02)$ and $44 \%(P<0.005)$ respectively. In the asthmatic remission group significant increases in leucocyte adenyl cyclase activity were observed-that is $64 \%$ $(P<0.005)$ and 92\% ( $P<0.001)$. However, no significant increase in enzyme activity was observed in the acute asthmatic group when the cells were stimulated with up to $10^{-4} \mathrm{~mol}$ isoprenaline/1. Ouabain at $2 \times 10^{-4} \mathrm{~mol} / 1$. caused a marginally significant increase in "H-cyclic AMP in the "remission" group but no change in the "acute" or normal groups. The combination of ouabain $2 \times 10^{-4} \mathrm{~mol} / 1$. and isoprenaline $10^{-4} \mathrm{~mol} / 1$. significantly stimulated leucocyte adenyl cyclase activity in all three groups.

Thymoxamine at $2 \times 10^{-4} \mathrm{~mol} / \mathrm{l}$. produced no increased enzyme activity in the three groups examined, but in combination with isoprenaline $10^{-4} \mathrm{~mol} / 1$. the increased activity in all three groups was highly significant. Similarly, phentolamine at $2 \times 10^{-4} \mathrm{~mol} / 1$. alone evoked no change in any group, but in combination with $10^{-4} \mathrm{~mol} / \mathrm{l}$. isoprenaline a highly significant increase was obtained in all three groups. The effect of isoprenaline stimulation of leucocyte adenyl cyclase compared 
with the mean values for forced expiratory volume and the mean eosinophil count expressed as a percentage of the total leucocyte count is shown in table IV.

\section{Discussion}

The increase in leucocyte ${ }^{3} \mathrm{H}$-cyclic AMP in the active or "acute" asthmatic group on stimulation with $10^{-4} \mathrm{M}$ isoprenaline was not significant $(12.4 \%)$ and was associated with a mean $\mathrm{FEV}_{1}$ of $56 \%$ for the group. This contrasts with the $93 \%$ increase in "H-cyclic AMP in the "remission" group with a mean $\mathrm{FEV}_{1}$ of $67 \%$. These findings are in agreement with our clinical division of the patients into those suffering from active or "acute" asthma and from asthma in remission. They are also in accord with the observations of Parker and Smith (1973) who found that not only was there a diminished responsiveness of leucocyte adenyl cyclase to isoprenaline stimulation associated with a more severe degree of airways obstruction but, in addition, two of their asthmatic patients showed a waxing and waning of this activity with remissions and exacerbations of the illness. The results of Logsdon et al. (1972 b), who found that most of their asthmatic patients had reduced responsiveness to isoprenaline, and those of Gillespie et al. (1973), who found that most of their asthmatic patients showed no difference from normal subjects in this respect, are difficult to explain, but it should be noted that these authors did not report measurements of airways obstruction in their patients. Since most of the leucocyte adenyl cyclase activity is in the lymphocytes it was important to eliminate changes in the differential leucocyte count in our series of patients. The differential counts (not tabulated here) did not show any alteration in the percentage of lymphocytes in either group. Nevertheless, we did observe a slightly higher eosinophil count in the acute asthmatic group associated with a lower $\mathrm{FEV}_{1}$ (table IV).

TABLE IV-Comparison of the Patients Suffering from Acute Asthma with those in Remission

\begin{tabular}{|c|c|c|c|c|}
\hline $\begin{array}{l}\text { Asthmatic } \\
\text { Condition }\end{array}$ & $\begin{array}{c}\text { Mean FEV } \\
\text { as Percentage } \\
\text { of Predicted } \\
\text { VC }\end{array}$ & Eosinophils & $\begin{array}{l}\text { No. of } \\
\text { Patients }\end{array}$ & $\begin{array}{l}\text { Increase in Cyclic AMP } \\
\text { in Response to } 10^{-4} \mathrm{~mol} \\
\text { Isoprenaline/1. in Terms } \\
\text { of control value of } 100 \% \\
\text { with } 10 \text { mmol Theophyl- } \\
\text { line } / 1 \text {. }\end{array}$ \\
\hline $\begin{array}{l}\text { Acute } \\
\text { In remission }\end{array}$ & $\begin{array}{l}56 \% \\
67 \%\end{array}$ & $\begin{array}{l}5 \cdot 1 \\
3.8\end{array}$ & $\begin{array}{l}7 \\
7\end{array}$ & $\begin{array}{l}112.4 \pm 10.6 \\
192.6 \pm 11.1\end{array}$ \\
\hline
\end{tabular}

The values for the individual patients were pooled and the means calculated.

It has been shown that the free fatty acid and glucose mobilization in response to adrenaline administration is diminished in patients with bronchial asthma as compared to normal subjects (Cookson and Reid, 1963; Middleton and Finke, 1968) and this reduced metabolic response to adrenaline administration varies with the severity of the asthma (Inoue, 1967). These observations, together with the reported reduction in the adenyl cyclase response to isoprenaline in leucocytes, support the view that the adrenergic receptor system reacts abnormally to sympathomimetic amines in acute asthma and that the same abnormal adrenergic response occurs in the airways.

The recently reported rise in asthmatic deaths has been linked with excessive use of isoprenaline inhalers, and it has been suggested that this results in a resistance to beta-adrenergic stimulants (Connolly et al., 1971). We have not been able to associate the diminished adenyl cyclase response to isoprenaline with earlier therapy involving the use of sympathomimetic amines. The significant difference in the value of the control or basal level of adenyl cyclase activity in the active asthmatic group compared with the group in remission, however, suggests that in acute asthma the adenyl cyclase system may be almost maximally stimulated by circulating endogenous catecholamines and that further stimulation with sympathomimetic amines becomes increasingly difficult, resulting in the adrenaline-fast state. This is the situation in status asthmaticus which leads to respiratory failure unless airways obstruction and the work of breathing is relieved by alternative therapy. The habitual use of isoprenaline may lead to an increased rate of metabolism in these patients, with accumulation of the metabolite 3-methoxyisoprenaline, which is a weak beta-adrenergic blocker (Jenkinson, 1973) and can contribute to diminished response to sympathomimetic amines.

Recent work (Prime et al., 1972) has drawn attention to the presence of alpha receptors on the bronchial smooth muscle with bronchoconstrictor activity, and Patel and Kerr (1973) have suggested that the defective beta-receptor response in asthmatics may lead to an increased alpha-receptor activity and give rise to bronchial hyperreactivity. We therefore studied the effect of the alpha-receptor blocking drugs in the experimental system. It is clear that phentolamine and thymoxamine restore the responsiveness of leucocyte adenyl cyclase activity to isoprenaline towards normal in acute asthma. Moreover, ouabain, a potent inhibitor of $\mathrm{Na}+$ and $\mathrm{K}+$ activated ATPase (Glynn, 1968), also restores the adenyl cyclase responsiveness to isoprenaline towards normal in the acute asthmatic group. The similarity of the action of ouabain to that of the alpha-blocking drugs supports the view that there is increased alpha-receptor activity in acute asthma, and that the membrane-bound enzyme $\mathrm{Na}+, \mathrm{K}+$ ATPase is closely associated with alpha-receptor activity. Coffey et al. (1972 a) have demonstrated with broken cell preparations that there is increased ATPase activity in the leucocytes of asthmatic children, and that this activity can be reduced towards normal by treatment with hydrocortisone, and also that the latter restores the responsiveness of the cells to isoprenaline stimulation. The delay which occurs before hydrocortisone relieves acute asthma is well-known and its relationship to adenyl cyclase requires further study. Moreover, alpha-receptor blocking drugs have been shown to restore the sensitivity of airways and have been used in the management of asthma (Marcelle et al., 1968). Further studies of leucocyteadenyl cyclase activity in active asthma and the functional imbalance of alpha- and beta-receptors should help to elucidate the relationship of these factors to the phenomenon of airways obstruction in asthma.

The authors wish to thank the Scottish Hospitals Endowment Research Trust for their generous support of this work.

\section{References}

Bourne, H. R., and Melmon, K. L. (1971). fournal of Pharmacology and Experimental Therapeutics, 178, 1.

Coffey, R. G., Logsdon, P. J., and Middleton, Jr., E. (1972 a). Fournal of Allergy and Clinical Immunology, 49, 87.

Connolly, M. E., Davis, D. S., Dollery, C. T., and George, C. F. (1971). Cookson, D. U., and Reed, C. E. (1963). American Review of Respiratory Disease, 88, 636.

Gillespie, E., Valentine, M. D., and Lichtenstein, L. M. (1973). Fournal of Allergy and Clinical Immunology, 51, 93 .

Glynn, I. M. (1968). British Medical Bulletin, 24, 165.

Humes, J. L., Rounbehler, M., and Kuehl, Jr., F. A. (1969). Analytical Biochemistry, 32, 210.

Inoue, S. (1967). Fournal of Allergy, 40, 337.

Jenkinson, D. H. (1973). British Medical Bulletin, 29, 142

Logsdon, P. J., Middleton, Jr., E., and Coffey, R. G. (1972 b). Fournal of Allergy and Clinical Immunology, 50, 45.

Marcelle, R., Bottin, R., Juchmes, J., and Lecomte, J. (1968). Acta Allergologica, 23, 11.

Middleton, Jr., E., and Finke, S. R. (1968). Fournal of Allergy, 42, 288.

Parker, C. W., and Smith, J. W. (1973). Fournal of Clinical Investigation, $52,48$.

Patel, K. R., and Kerr, J. W. (1973). Clinical Allergy. (in Press.)

Prime, F. J., Bianco, S., Griffin, J. P., and Kamburoff, P. L. (1972). Bulletin de Physio-Pathologie Respiratoire, 8, 99.

Robison, G. A., Butcher, R. W., and Sutherland, E. W. (1967). Annals of the New York Academy of Sciences, 139, 703.

Scott, R. E. (1970). Blood, 35, 514.

Smith, J. W., and Parker, C. W. (1970). Fournal of Laboratory and Clinical Medicine, 76, 993.

Szentivanyi, A. (1968). Fournal of Allergy, 42, 203. 